\title{
Laparoscopic vs. open approach for colorectal cancer: evolution over time of minimal invasive surgery
}

\author{
Antonio Biondi ${ }^{*}$, Giuseppe Grosso ${ }^{2}$, Antonio Mistretta ${ }^{3}$, Stefano Marventano ${ }^{3}$, Chiara Toscano ${ }^{1}$, Filippo Drago ${ }^{4}$, \\ Santi Gangi ${ }^{1}$, Francesco Basile ${ }^{1}$
}

From 26th National Congress of the Italian Society of Geriatric Surgery

Naples, Italy. 19-22 June 2013

\begin{abstract}
Background: In the late '80s the successes of the laparoscopic surgery for gallbladder disease laid the foundations on the modern use of this surgical technique in a variety of diseases. In the last 20 years, laparoscopic colorectal surgery had become a popular treatment option for colorectal cancer patients.

Discussion: Many studies emphasized on the benefits stating the significant advantages of the laparoscopic approach compared with the open surgery of reduced blood loss, early return of intestinal motility, lower overall morbidity, and shorter duration of hospital stay, leading to a general agreement on laparoscopic surgery as an alternative to conventional open surgery for colon cancer. The reduced hospital stay may also decrease the cost of the laparoscopic surgery for colorectal cancer, despite th higher operative spending compared with open surgery. The average reduction in total direct costs is difficult to define due to the increasing cost over time, making challenging the comparisons between studies conducted during a time range of more than 10 years. However, despite the theoretical advantages of laparoscopic surgery, it is still not considered the standard treatment for colorectal cancer patients due to technical limitations or the characteristics of the patients that may affect short and long term outcomes.

Conclusions: The laparoscopic approach to colectomy is slowly gaining acceptance for the management of colorectal pathology. Laparoscopic surgery for colon cancer demonstrates better short-term outcome, oncologic safety, and equivalent long-term outcome of open surgery. For rectal cancer, laparoscopic technique can be more complex depending on the tumor location. The advantages of minimally invasive surgery may translate better care quality for oncological patients and lead to increased cost saving through the introduction of active enhanced recovery programs which are likely cost-effective from the perspective of the hospital health-care providers.
\end{abstract}

\section{Background}

Despite the decreased incidence rates reported during last years, cancer remain the leading cause of death worldwide [1]. It has been reported that only a small part of cancers is genetically determined, and most of them is due to a biological response to environmental factors [2-6]. Interventions focused on primary prevention

\footnotetext{
* Correspondence: abiondi@unict.it

'Department of General Surgery, Section of General Surgery and Oncology, University Medical School of Catania, Italy

Full list of author information is available at the end of the article
}

mostly regard tobacco smoking, alcohol consumption, and dietary advices $[7,8]$, but the burden of the disease is far to be considered negligible. Regarding the therapeutic approaches, in the late ' 80 s the successes of the laparoscopic surgery for gallbladder disease laid the foundations on the modern use of this surgical technique in a variety of diseases [9-14]. Among the most frequent benign and malignant disease which require a surgical therapy, colorectal cancer has reached the best results with a laparoscopic approach in terms of safety [15], reduced
C Biomed Central 
postoperative recovery [16], and improved long-term survival $[17,18]$.

Thus, in the last 20 years, laparoscopic colorectal surgery had become a popular treatment option for colorectal cancer patients. Several clinical trials emphasized the aforementioned benefits stating the significant advantages of reduced blood loss, early return of intestinal motility, lower overall morbidity, and shorter duration of hospital stay in the laparoscopic-assisted group, leading to a general agreement on laparoscopic surgery as an alternative to conventional open surgery for colon cancer. However, despite the theoretical advantages of laparoscopic surgery, it is still not considered the standard treatment for colorectal cancer patients due to technical limitations or characteristics of the patients that may affect short and long term outcomes [19]. Thus, the aim of this study is to review the main available evidences between the conventional open approach and laparoscopic resection of colorectal cancer treatment.

\section{Operative parameters}

Results about mean operating time of the laparoscopicassisted procedure versus open surgery vary among studies, some reporting no significant differences between the two groups $[20,21]$ and others reporting a longer time for the laparoscopic-assisted procedure [22].

The prolonged operative time for the laparoscopic procedure depend on the higher complexity of technical expertise involved in such technique. Given the technical difficulty of this treatment, reasons of such results may be depended by the need for experienced surgeons and a not well established manuality due to a consistent learning curve $[23,24]$. Major difficulties of the laparoscopic colorectal surgery are due to work in multiple abdominal quadrants, control of vascular structures, creation of anastomosis, as well as retrieving large specimens in some patients whereas potential risks regard port-site recurrence after curative resection of tumor and incomplete lymph node dissection $[25,26]$. More recent studies are reporting less significant differences according to this parameter thanks to the stabilization of the learning curve of the surgeon. Indeed, in most of the reports, the learning curve of the technique is incorporated during the study period and the skills were still evolving during the conduct of the study, thus is not surprising that as time passed, the surgeon's experience with the procedure increased as well, leading to a decrease of the operative time in the latter phase of the study period.

Blood loss and analgesic requirement depend greatly on the degree of invasiveness of the surgical approach. Results of a recent meta-analysis of clinical trials revealed a significant increased reduction of intraoperative blood loss, number of blood transfusions, and abdominal bleeding in patients who underwent a laparoscopic colon resection compared with those operated with an open approach [27].

\section{Short-term outcomes}

Early randomized controlled trials suggested that the short-term outcomes of laparoscopic colorectal surgeries were similar or barely better than the traditional open approach.

With the establishment of the technique as a routine surgical approach, a study conducted in 48 institutions (namely including many surgeons) on 872 patients, reported that a greater experience of the surgeon (20 or more laparoscopic resections) was associated with longer operating time, but better outcomes such as lower intraoperative complications and shorter recovery time and hospital stay [28].

The significant improvements in postoperative recovery among laparoscopic-treated patients regard mostly an earlier resumption of normal diet, shorter hospital stay, and earlier time to ambulation [20].

However, comparison of length of hospital stay after surgery among studies may be affected by some confounding factors. For instance, socioeconomic status may lead to health care disparities in countries such as the US where insurance play an important role on health care of population. Thus, compared with countries in which the healthcare system provides ensuring equity in the availability of care by removing financial barriers for all patients, the hospital stay of colorectal cancer patients living in US has been reported to be shorter [29]. Taking into account such possible bias, a country-specific comparison of the length of hospital stay of the patients operated with the laparoscopic and open procedure still remain significantly different. Indeed, the postoperative hospital stay for patients who undergo the laparoscopic procedure has been reported to range between about 5 and 7 days in US $[28,30,31]$ and slightly longer in countries in which care are free of charge for all patients [20], compared with 8 to 10 days for those who undergo open surgery.

The benefits in short-term outcomes with laparoscopic resection has been also supported by the reports on perioperative immunologic response [32,33]. In the early post-operative period, better reserved cellular immune responses such as higher levels of total lymphocytes, CD4 $\mathrm{T}$ cell, and CD8 $\mathrm{T}$ cell in laparoscopic resection compared with open resection was observed [34]. In some studies exploring the inflammatory response differences among different surgical techniques, the immunologically beneficial IFN- $\gamma$, produced by the principal effectors of cell-mediated immunity Th1 cells, seemed to have a more active presence following laparoscopic colectomy, potentially contributing to an immunologic "advantage" by counteracting "harmful" cytokines, such as IL-1 
$[35,36]$. Better preserved inflammatory function after surgery may reflect a reduction in operative trauma when the laparoscopic technique is compared with open procedures.

\section{Long-term outcomes}

Body's immunologic function, especially cellular immunity, play a central role in preventing cancer recurrence immediately after surgery of oncological patients [37]. Since the laparoscopic approach limits the tissue trauma and lead to significant less physiologic alterations during the perioperative period, it has been hypothesized that this increased preservation of the immunologic function may be translated in better long-term oncologic outcomes and may be correlated with higher postoperative survival rates [38-40]. Although evidence from early basic science studies seems to be promising, results from human studies are contrasting.

In terms of overall survival, disease-free survival, local or distant recurrence, and long-term quality of life for colon cancer, recent trials results did not show difference between the two groups, laparoscopic and laparotomy resection [41].

Others multicentre and randomized trials have extended patient recruitment including individuals affected by rectal cancer, considering the same parameters $[30,42,43]$.

Taking into consideration the same data, some authors have performed some meta-analyses reporting generally equal long term outcomes [34,44,45]. Oncological safety of patients operated with laparoscopic approach strongly depends on the experience of the surgeon, that has been shown to lead to better long-term outcomes, even when comparing laparoscopic to open surgery $[28,30,42]$. The studies pointed out also the risk connected with conversion rates, which are indeed reduced by increasing the experience of the surgeon. Some reports suggested that the conversion to open does not affect the general patient long-term outcomes [46], whereas others have shown an increase in the morbidity of inpatients and related outcomes [47-49]. In most cases the conversion depends on advanced cancer stage or, among the most reported reasons, on technical difficulties, obesity, and intra-operatory complications, but since the adverse impact of conversion has been reported to affect the overall survival (and not the disease-free survival), this finding is not attributable to a surgeon-related factor [41].

The problem with incision site recurrences is certainly not a new issue in surgical oncology, but it remains unclear whether if laparoscopy is significantly affected by this issue and what are the mechanisms responsible [50]. For this reason, during the operation, manipulation of the tumor must be avoided; this is possible thanks to the use of non-traumatic forceps but above all thanks to the technique used that provides the fixity of the intestine during the entire surgery, only at the end, its mobilization. The most risky moment is the opening of the abdominal portion for the extraction of the removed piece, during which also happens the deflating of the pneumoperitoneum. The rapid deflation of the pneumoperitoneum may determine the so called "chimney effect" consequently with neoplastic parietal dissemination and the trocar sites. These two events can be avoided using small steps such as the use of endobag and a gradual desufflation with a laparoscopic extractor fan. The volume and extension of the mass are elements that affect contamination of surgical instruments during surgery and the consequential dissemination of neoplastic cells because, when the mass grows on the intestinal serosa or has infiltrated the mesentery and the surrounding structures, contamination becomes inevitable [51-57].

Previous trials reported higher recurrence rates among laparoscopic operated patients compared with those operated with the open approach (up to $80 \%$ within 12 months), but latest updates from large randomized control trials do not confirm such rates, reporting comparable results between the two techniques (ranging from $0.5 \%$ and $1.3 \%)[31,54,58]$.

Incisional hernia and adhesions are also a cause of postoperative morbidity and predictors of long term adverse outcome. Regarding incisional hernia, it has been reported that laparoscopic technique may have some advantages compared with open surgery [59-61], due to the absence of a large abdominal wound $[62,63]$. Moreover, some authors have reported lower rates of formation of adhesions and related complications in the laparoscopic compared with open group [64-68].

\section{Cost analysis}

Despite the laparoscopic approach has proved as useful for many benign conditions, including diverticulitis, Crohn's disease, and rectal prolapse, the cost-effectiveness and long-term outcomes for malignancy are less well accepted. Earlier studies comparing costs from colectomy by the laparoscopic and open approaches reported conflicting results. Some studies reported costs for laparoscopic colectomy to be greater than for open surgery $[69,70]$ mostly due to higher operative spending for laparoscopy, rising the doubt that the laparoscopic colorectal resection could be potentially less cost-effective than open surgery. Indeed, the care of patients undergoing colorectal surgery is associated with a variety of direct costs related to the operating equipment and consumables, anesthesia, laboratory, radiology, and pharmacy. The laparoscopic approach has been demonstrated that require greater costs related to longer operative time and more expensive equipment. 
On the other hand, studies started to focus on many other aspects of the comparison between the two techniques, analyzing whether laparoscopic operating room costs were balanced by postoperative care savings [71]. Indeed, compared with conventional open resections, laparoscopic colorectal resections are associated with less invasive incision sizes, less postoperative ileus and earlier tolerance of diet which may contribute to less need for analgesic treatment and earlier recovery of the patient with a reduced hospital stay. A faster hospital recovery has been demonstrated to translate significantly lower total costs owing to lower pharmacy, laboratory, and ward nursing costs. Reduced analgesia requirements and lower occurrence of complications may also decrease costs associated with laparoscopic treatment. However, studies reporting differences between the two procedures are equivocal.

The most recent reports concluded that laparoscopic colorectal resections are significantly cheaper than conventional open resections because of the reduced hospital stay, despite higher operative spending. The average reduction in total direct costs is difficult to define due to the increasing cost over time making comparisons between studies conducted during a time range of more than 10 years. Moreover, the costs may vary according to region or country in which the study was performed. The saving cost estimated per case has been reported to range from about $\$ 50$ to $\$ 500$. However, the analysis of the source of such costs demonstrates that this reduction is derived mostly from nursing care, pharmacy, and laboratory costs which compensate the increased operating room expenses incurred by laparoscopic surgery. On the other hand, newly designed "fast-track" care for colectomy patients may narrow the distinctions between hospital stay of laparoscopic and open colectomy because of the perception that length of stay can be dramatically reduced with open surgery [72-75].

\section{Conclusions}

The laparoscopic approach to colectomy is slowly gaining acceptance for the management of colorectal pathology. Laparoscopic surgery for colon cancer demonstrates better short-term outcome, oncologic safety, and equivalent long-term outcome of open surgery. For rectal cancer, laparoscopic technique can be more complex depending on the tumor location. However, improvements in health outcomes have been reported also for rectal location of cancers, with comparable results to open surgery when the experience of the surgeon is well established. The advantages of minimally invasive surgery may translate better care quality for oncological patients and lead to increased cost saving through the introduction of active enhanced recovery programs which are likely cost-effective from the perspective of the hospital health-care providers.

\section{Competing interests}

The authors declare that they have no competing interests.

\section{Authors' contributions}

$A B$ : conception and design, drafting the manuscript; GG, AM, SM, CT: drafting the manuscript; FD, SG, FB: critical revision, given final approval of the version to be published.

\section{Acknowledgements}

Giuseppe Grosso was supported by the International Ph.D. Program in Neuropharmacology, University of Catania Medical School, Catania, Italy. The funders had no role in the study design, data collection and analysis, decision to publish, or preparation of the manuscript.

\section{Declarations}

Funding of this article came from University funds.

This article has been published as part of BMC Surgery Volume 13 Supplement 2, 2013: Proceedings from the 26th National Congress of the Italian Society of Geriatric Surgery. The full contents of the supplement are available online at http://www.biomedcentral.com/bmcsurg/supplements/13/S2

\section{Authors' details}

'Department of General Surgery, Section of General Surgery and Oncology, University Medical School of Catania, Italy. ${ }^{2}$ Department of Drug Sciences, Section of Biochemistry, University of Catania, Catania, Italy. ${ }^{3}$ Department "G. F. Ingrassia" Section of Hygiene and Public Health, University of Catania, Catania, Italy. ${ }^{4}$ Department of Clinical and Molecular Biomedicine, Section of Pharmacology and Biochemistry, University of Catania, Catania, Italy.

Published: 8 October 2013

\section{References}

1. Haggar FA, Boushey RP: Colorectal cancer epidemiology: incidence, mortality, survival, and risk factors. Clinics in colon and rectal surgery 2009, 22(4):191-197.

2. Ragusa M, Statello L, Maugeri M, Majorana A, Barbagallo D, Salito L, Sammito M, Santonocito M, Angelica R, Cavallaro A, et al: Specific alterations of the microRNA transcriptome and global network structure in colorectal cancer after treatment with MAPK/ERK inhibitors. $J \mathrm{Mol}$ Med (Berl) 2012, 90(12):1421-1438.

3. Ragusa M, Majorana A, Statello L, Maugeri M, Salito L, Barbagallo D, Guglielmino MR, Duro LR, Angelica R, Caltabiano R, et al: Specific alterations of microRNA transcriptome and global network structure in colorectal carcinoma after cetuximab treatment. Molecular cancer therapeutics 2010, 9(12):3396-3409.

4. Biondi A, Fisichella R, Fiorica F, Malaguarnera M, Basile F: Food mutagen and gastrointestinal cancer. European review for medical and pharmacological sciences 2012, 16(9):1280-1282.

5. Uccello M, Malaguarnera G, Corriere T, Biondi A, Basile F, Malaguarnera M: Risk of hepatocellular carcinoma in workers exposed to chemicals. Hepatitis monthly 2012, 12(10 HCC):e5943.

6. Berretta M, Lleshi A, Fisichella R, Berretta S, Basile F, Li Volti G, Bolognese A, Biondi A, De Paoli $P$, Tirelli $U$, et al: The role of nutrition in the development of esophageal cancer: what do we know? Front Biosci (Elite Ed) 2012, 4:351-357.

7. Frieden TR, Myers JE, Krauskopf MS, Farley TA: A public health approach to winning the war against cancer. The oncologist 2008, 13(12):1306-1313.

8. Uccello M, Malaguarnera G, Basile F, D'Agata V, Malaguarnera M, Bertino G, Vacante $M$, Drago F, Biondi A: Potential role of probiotics on colorectal cancer prevention. BMC surgery 2012, 12(Suppl 1):S35.

9. Terblanche J: Laparoscopic cholecystectomy: a new milestone or a dangerous innovation? HPB surgery : a world journal of hepatic, pancreatic and biliary surgery 1991, 3(3):177-180.

10. Cantore F, Colombo EM, Giuseppe MD, Biondi A, Rausei S, Dionigi G, Rovera F, Boni L, Dionigi R: Single access cholecystectomy using standard laparoscopic instruments. Updates in surgery 2011, 63(1):31-34.

11. Biondi A, Tropea A, Basile F: Clinical rescue evaluation in laparoscopic surgery for hepatic metastases by colorectal cancer. Surgical laparoscopy, endoscopy \& percutaneous techniques 2010, 20(2):69-72. 
12. Testini M, Piccinni G, Lissidini G, Di Venere B, Gurrado A, Poli E, Brienza N, Biondi A, Greco L, Nacchiero M: Management of descending duodenal injuries secondary to laparoscopic cholecystectomy. Digestive surgery 2008, 25(1):12-15.

13. Agresta F, De Simone P, Leone L, Arezzo A, Biondi A, Bottero L, Catena F, Conzo G, Del Genio G, Fersini A, et al: Laparoscopic appendectomy in Italy: an appraisal of 26,863 cases. Journal of laparoendoscopic \& advanced surgical techniques Part A 2004, 14(1):1-8.

14. Biondi A, Motta S, Di Giunta M, Crisafi RM, Zappala S, Rapisarda D, Basile F: [The use of laparoscopy for diagnosis and stadiation of the lymphomas]. Annali italiani di chirurgia 2009, 80(6):445-447.

15. Jacobs M, Verdeja JC, Goldstein HS: Minimally invasive colon resection (laparoscopic colectomy). Surgical laparoscopy \& endoscopy 1991, 1(3):144-150.

16. Lacy AM, Garcia-Valdecasas JC, Delgado S, Castells A, Taura P, Pique JM, Visa J: Laparoscopy-assisted colectomy versus open colectomy for treatment of non-metastatic colon cancer: a randomised trial. Lancet 2002, 359(9325):2224-2229.

17. Kuntz C, Wunsch A, Rosch R, Autschbach F, Windeler J, Herfarth C: Shortand long-term results after laparoscopic vs conventional colon resection in a tumor-bearing small animal model. Surgical endoscopy 2000, 14(6):561-567.

18. Biondi A, Grosso G, Mistretta A, Marventano S, Toscano C, Gruttadauria S, Basile F: Laparoscopic-assisted versus open surgery for colorectal cancer: short- and long-term outcomes comparison. Journal of laparoendoscopic \& advanced surgical techniques Part A 2013, 23(1):1-7.

19. Vacante M, D'Agata V, Motta M, Malaguarnera G, Biondi A, Basile F, Malaguarnera M, Gagliano C, Drago F, Salamone S: Centenarians and supercentenarians: a black swan. Emerging social, medical and surgical problems. BMC surgery 2012, 12(Suppl 1):S36.

20. Sun J, Jiang T, Qiu Z, Cen G, Cao J, Huang K, Pu Y, Liang H, Huang R, Chen $\mathrm{S}$ : Short-term and medium-term clinical outcomes of laparoscopicassisted and open surgery for colorectal cancer: a single center retrospective case-control study. BMC gastroenterology 2011, 11:85.

21. Kim HJ, Lee IK, Lee YS, Kang WK, Park JK, Oh ST, Kim JG, Kim YH: A comparative study on the short-term clinicopathologic outcomes of laparoscopic surgery versus conventional open surgery for transverse colon cancer. Surgical endoscopy 2009, 23(8):1812-1817.

22. Li JC, Leung KL, Ng SS, Liu SY, Lee JF, Hon SS: Laparoscopic-assisted versus open resection of right-sided colonic cancer-a prospective randomized controlled trial. International journal of colorectal disease 2012 , 27(1):95-102

23. Kye BH, Kim JG, Cho HM, Kim HJ, Suh YJ, Chun CS: Learning curves in laparoscopic right-sided colon cancer surgery: a comparison of firstgeneration colorectal surgeon to advance laparoscopically trained surgeon. Journal of laparoendoscopic \& advanced surgical techniques Part A 2011, 21(9):789-796.

24. Miskovic D, Ni M, Wyles SM, Tekkis P, Hanna GB: Learning curve and case selection in laparoscopic colorectal surgery: systematic review and international multicenter analysis of 4852 cases. Diseases of the colon and rectum 2012, 55(12):1300-1310.

25. Fazio WW, Lopez-Kostner F: Role of laparoscopic surgery for treatment of early colorectal carcinoma. World journal of surgery 2000, 24(9):1056-1060

26. Bennett CL, Stryker SJ, Ferreira MR, Adams J, Beart RW Jr: The learning curve for laparoscopic colorectal surgery. Preliminary results from a prospective analysis of 1194 laparoscopic-assisted colectomies. Arch Surg 1997, 132(1):41-44, discussion 45.

27. Trastulli S, Cirocchi R, Listorti C, Cavaliere D, Avenia N, Gulla N, Giustozzi G, Sciannameo F, Noya G, Boselli C: Laparoscopic vs open resection for rectal cancer: a meta-analysis of randomized clinical trials. Colorectal disease : the official journal of the Association of Coloproctology of Great Britain and Ireland 2012, 14(6):e277-296.

28. Clinical Outcomes of Surgical Therapy Study Group: A comparison of laparoscopically assisted and open colectomy for colon cancer. The New England journal of medicine 2004, 350(20):2050-2059.

29. Jensen CC, Prasad LM, Abcarian H: Cost-effectiveness of laparoscopic vs open resection for colon and rectal cancer. Diseases of the colon and rectum 2012, 55(10):1017-1023.

30. Guillou PJ, Quirke P, Thorpe H, Walker J, Jayne DG, Smith AM, Heath RM, Brown JM: Short-term endpoints of conventional versus laparoscopicassisted surgery in patients with colorectal cancer (MRC CLASICC trial): multicentre, randomised controlled trial. Lancet 2005 365(9472):1718-1726

31. Fleshman J, Sargent DJ, Green E, Anvari M, Stryker SJ, Beart RW Hellinger M, Flanagan R, Peters W, Nelson H: Laparoscopic colectomy for cancer is not inferior to open surgery based on 5-year data from the COST Study Group trial. Annals of surgery 2007, 246(4):655-662, discussion 662-654.

32. Novitsky YW, Litwin DE, Callery MP: The net immunologic advantage of laparoscopic surgery. Surgical endoscopy 2004, 18(10):1411-1419.

33. Saenz J, Asuero MS, Villafruela J, Correa C, Galindo J, Cuevas B, Paez A, Linares A, Pascual J, Marcen R, et al: Immunohumoral response during laparoscopic and open living donor nephrectomy: an experimental model. Transplantation proceedings 2007, 39(7):2102-2104.

34. Huang C, Huang R, Jiang T, Huang K, Cao J, Qiu Z: Laparoscopic and open resection for colorectal cancer: an evaluation of cellular immunity. $B M C$ gastroenterology 2010, 10:127.

35. Veenhof $A A$, Sietses $C$, von Blomberg BM, van Hoogstraten IM, vd Pas $M H_{\text {, }}$ Meijerink WJ, vd Peet DL, vd Tol MP, Bonjer HJ, Cuesta MA: The surgical stress response and postoperative immune function after laparoscopic or conventional total mesorectal excision in rectal cancer: a randomized trial. International journal of colorectal disease 2011, 26(1):53-59.

36. Tsamis D, Theodoropoulos G, Stamopoulos P, Siakavellas S, Delistathi T, Michalopoulos NV, Zografos GC: Systemic inflammatory response after laparoscopic and conventional colectomy for cancer: a matched casecontrol study. Surgical endoscopy 2012, 26(5):1436-1443.

37. Kumara HM, Feingold D, Kalady M, Dujovny N, Senagore A, Hyman N, Cekic V, Whelan RL: Colorectal resection is associated with persistent proangiogenic plasma protein changes: postoperative plasma stimulates in vitro endothelial cell growth, migration, and invasion. Annals of surgery 2009, 249(6):973-977.

38. Southall JC, Lee SW, Allendorf JD, Bessler M, Whelan RL: Colon adenocarcinoma and B-16 melanoma grow larger following laparotomy vs. pneumoperitoneum in a murine model. Diseases of the colon and rectum 1998, 41(5):564-569.

39. Allendorf JD, Bessler M, Kayton ML, Oesterling SD, Treat MR, Nowygrod R, Whelan RL: Increased tumor establishment and growth after laparotomy vs laparoscopy in a murine model. Arch Surg 1995, 130(6):649-653.

40. Lee SW, Feingold DL, Carter JJ, Zhai C, Stapleton G, Gleason N, Whelan RL: Peritoneal macrophage and blood monocyte functions after open and laparoscopic-assisted cecectomy in rats. Surgical endoscopy 2003, 17(12):1996-2002.

41. Jayne DG, Thorpe HC, Copeland J, Quirke P, Brown JM, Guillou PJ: Five-year follow-up of the Medical Research Council CLASICC trial of laparoscopically assisted versus open surgery for colorectal cancer. The British journal of surgery 2010, 97(11):1638-1645.

42. Veldkamp R, Kuhry E, Hop WC, Jeekel J, Kazemier G, Bonjer HJ, Haglind E, Pahlman L, Cuesta MA, Msika S, et al: Laparoscopic surgery versus open surgery for colon cancer: short-term outcomes of a randomised trial. The lancet oncology 2005, 6(7):477-484.

43. Tang CL, Eu KW, Tai BC, Soh JG, MacHin D, Seow-Choen F: Randomized clinical trial of the effect of open versus laparoscopically assisted colectomy on systemic immunity in patients with colorectal cancer. The British journal of surgery 2001, 88(6):801-807.

44. Aziz O, Constantinides V, Tekkis PP, Athanasiou T, Purkayastha S, Paraskeva P, Darzi AW, Heriot AG: Laparoscopic versus open surgery for rectal cancer: a meta-analysis. Annals of surgical oncology 2006, 13(3):413-424

45. Bonjer HJ, Hop WC, Nelson H, Sargent DJ, Lacy AM, Castells A, Guillou PJ, Thorpe H, Brown J, Delgado S, et al: Laparoscopically assisted vs open colectomy for colon cancer: a meta-analysis. Arch Surg 2007, 142(3):298-303.

46. Le Moine MC, Fabre JM, Vacher C, Navarro F, Picot MC, Domergue J: Factors and consequences of conversion in laparoscopic sigmoidectomy for diverticular disease. The British journal of surgery 2003, 90(2):232-236.

47. Casillas S, Delaney CP, Senagore AJ, Brady K, Fazio WW: Does conversion of a laparoscopic colectomy adversely affect patient outcome? Diseases of the colon and rectum 2004, 47(10):1680-1685.

48. Marusch F, Gastinger I, Schneider C, Scheidbach H, Konradt J, Bruch HP, Kohler L, Barlehner E, Kockerling F: Importance of conversion for results obtained with laparoscopic colorectal surgery. Diseases of the colon and rectum 2001, 44(2):207-214, discussion 214-206 
49. Moloo H, Mamazza J, Poulin EC, Burpee SE, Bendavid Y, Klein L, Gregoire R, Schlachta CM: Laparoscopic resections for colorectal cancer: does conversion survival? Surgical endoscopy 2004, 18(5):732-735.

50. Zmora O, Weiss EG: Trocar site recurrence in laparoscopic surgery for colorectal cancer. Myth or real concern? Surgical oncology clinics of North America 2001, 10(3):625-638.

51. Alexander RJ, Jaques BC, Mitchell KG: Laparoscopically assisted colectomy and wound recurrence. Lancet 1993, 341(8839):249-250.

52. Wexner SD, Cohen SM: Port site metastases after laparoscopic colorectal surgery for cure of malignancy. The British journal of surgery 1995, 82(3):295-298.

53. Vukasin P, Ortega AE, Greene FL, Steele GD, Simons AJ, Anthone GJ, Weston LA, Beart RW Jr: Wound recurrence following laparoscopic colon cancer resection. Results of the American Society of Colon and Rectal Surgeons Laparoscopic Registry. Diseases of the colon and rectum 1996, 39(10 Suppl):S20-23.

54. Lacy AM, Delgado S, Castells A, Prins HA, Arroyo V, Ibarzabal A, Pique JM: The long-term results of a randomized clinical trial of laparoscopyassisted versus open surgery for colon cancer. Annals of surgery 2008, 248(1):1-7.

55. Johnstone PA, Rohde DC, Swartz SE, Fetter JE, Wexner SD: Port site recurrences after laparoscopic and thoracoscopic procedures in malignancy. Journal of clinical oncology : official journal of the American Society of Clinical Oncology 1996, 14(6):1950-1956.

56. Hughes ES, McDermott FT, Polglase AL, Johnson WR: Tumor recurrence in the abdominal wall scar tissue after large-bowel cancer surgery. Diseases of the colon and rectum 1983, 26(9):571-572.

57. Ceccarelli G, Casciola L, Nati S, Bartoli A, Spaziani A, Stefanoni M, Conti D, Fettucciari V, Di Zitti L, Valeri R, et al: [Neoplastic residues in the trocar tract in oncologic laparoscopic surgery]. Minerva chirurgica 2004, 59(3):243-248.

58. Buunen M, Veldkamp R, Hop WC, Kuhry E, Jeekel J, Haglind E, Pahlman L, Cuesta MA, Msika S, Morino M, et al: Survival after laparoscopic surgery versus open surgery for colon cancer: long-term outcome of a randomised clinical trial. The lancet oncology 2009, 10(1):44-52.

59. Duepree HJ, Senagore AJ, Delaney CP, Fazio WW: Does means of access affect the incidence of small bowel obstruction and ventral hernia after bowel resection? Laparoscopy versus laparotomy. Journal of the American College of Surgeons 2003, 197(2):177-181.

60. Audebert AJ, Gomel V: Role of microlaparoscopy in the diagnosis of peritoneal and visceral adhesions and in the prevention of bowel injury associated with blind trocar insertion. Fertility and sterility 2000, 73(3):631-635.

61. Biondi A, Tropea A, Monaco G, Musmeci N, Zanghi G, Basile F: [Complications in the laparoscopic treatment of primary and secondary hernias of the abdominal wall]. Annali italiani di chirurgia 2010, 81(3):193-198.

62. Podnos YD, Jimenez JC, Wilson SE, Stevens CM, Nguyen NT: Complications after laparoscopic gastric bypass: a review of 3464 cases. Arch Surg 2003, 138(9):957-961.

63. Coda A, Bossotti M, Ferri F, Mattio R, Ramellini G, Poma A, Quaglino F, Filippa C, Bona A: Incisional hernia and fascial defect following laparoscopic surgery. Surgical laparoscopy, endoscopy \& percutaneous techniques 2000, 10(1):34-38.

64. Grosso G, Biondi A, Marventano S, Mistretta A, Calabrese G, Basile F: Major postoperative complications and survival for colon cancer elderly patients. BMC surgery 2012, 12(Suppl 1):S20.

65. Hiki N, Shimizu N, Yamaguchi H, Imamura K, Kami K, Kubota K, Kaminishi M: Manipulation of the small intestine as a cause of the increased inflammatory response after open compared with laparoscopic surgery. The British journal of surgery 2006, 93(2):195-204.

66. Lumley J, Stitz R, Stevenson A, Fielding G, Luck A: Laparoscopic colorectal surgery for cancer: intermediate to long-term outcomes. Diseases of the colon and rectum 2002, 45(7):867-872, discussion 872-865.

67. Polymeneas G, Theodosopoulos T, Stamatiadis A, Kourias E: A comparative study of postoperative adhesion formation after laparoscopic vs open cholecystectomy. Surgical endoscopy 2001, 15(1):41-43.

68. Dowson HM, Bong JJ, Lovell DP, Worthington TR, Karanjia ND, Rockall TA: Reduced adhesion formation following laparoscopic versus open colorectal surgery. The British journal of surgery 2008, 95(7):909-914.
69. Philipson BM, Bokey EL, Moore JW, Chapuis PH, Bagge E: Cost of open versus laparoscopically assisted right hemicolectomy for cancer. World journal of surgery 1997, 21(2):214-217.

70. Bokey EL, Moore JW, Chapuis PH, Newland RC: Morbidity and mortality following laparoscopic-assisted right hemicolectomy for cancer. Diseases of the colon and rectum 1996, 39(10 Suppl):S24-28.

71. Ridgway PF, Boyle E, Keane FB, Neary P: Laparoscopic colectomy is cheaper than conventional open resection. Colorectal disease: the official journal of the Association of Coloproctology of Great Britain and Ireland 2007, 9(9):819-824.

72. Basse L, Hjort Jakobsen D, Billesbolle P, Werner M, Kehlet H: A clinical pathway to accelerate recovery after colonic resection. Annals of surgery 2000, 232(1):51-57.

73. Delaney CP, Fazio WW, Senagore AJ, Robinson B, Halverson AL, Remzi FH: 'Fast track' postoperative management protocol for patients with high co-morbidity undergoing complex abdominal and pelvic colorectal surgery. The British journal of surgery 2001, 88(11):1533-1538.

74. Cardin F, Andreotti A, Zorzi M, Terranova C, Martella B, Amato B, Militello C: Usefulness of a fast track list for anxious patients in a upper GI endoscopy. BMC Surgery 2012, 12(Suppl 1):S11.

75. Rispoli C, Rocco N, lannone L, Amato B: Developing guidelines in geriatric surgery:role of the grade system. BMC Geriatrics 2009, 9(SUPPL.1):A99.

doi:10.1186/1471-2482-13-S2-S12

Cite this article as: Biondi et al.: Laparoscopic vs. open approach for colorectal cancer: evolution over time of minimal invasive surgery. BMC Surgery 2013 13(Suppl 2):S12.

\section{Submit your next manuscript to BioMed Central and take full advantage of:}

- Convenient online submission

- Thorough peer review

- No space constraints or color figure charges

- Immediate publication on acceptance

- Inclusion in PubMed, CAS, Scopus and Google Scholar

- Research which is freely available for redistribution 